\title{
Accessibility of Rice Farmers to the Ghana School Feeding Programme and its Effect on Output
}

\author{
A. F. Shaibu, R. M. Al-Hassan \\ Department of Agricultural Economics and Agribusiness, University of Ghana, Legon Accra, Ghana
}

\begin{abstract}
The Ghana School Feeding Programme (GSFP) is the Ghanaian version of a Home-Grown School Feeding Programme (HGSP) that has a mandate to give one hot meal a day to school children in public schools from kindergarten through to primary six. The programme was launched in 2005 with the goal of contributing to poverty reduction and increased food security in Ghana. One of the key objectives of the programme is to boost domestic food production by sourcing GSFP raw materials locally, and providing a sustainable market for local food producers in the community. To analyse accessibility of rice farmers to the Ghana School Feeding Programme and its effect on production in three districts of the Northern Region of Ghana, a formal cross section survey of 100 small holder rice farmers was conducted. The transcendental logarithmic production function was applied to analyse the programme's effect on rice output in the three districts using access to the GSFP and other input variables. Our results show that farm labour, farm size, and fertilizer application were significant in increasing farmers' output while access to the GSFP market was not. Again there is no significant difference between the output of those who had access to the school feeding programme and those who do not.
\end{abstract}

\section{Keywords:}

Accessibility, effect, production, Ghana School Feeding Programme and rice farmers.

\section{Introduction}

Halving hunger by the year 2015 is one of the fundamental objectives of the Millennium Development Goals (MDGs). According to the 2009 Global Hunger Index, Ghana was making relatively good progress in addressing food insecurity. It was the only country in sub-Saharan Africa to cut its score by half in from 23.5 in 1990 to 11.5 in 2009. The Ghanaian economy grew at an average rate of $6.7 \%$ over the period, 2007 to 2010 . In 2011, the agricultural sector contributed $25.6 \%$ to GDP and the economy continues to revolve around subsistence agriculture which employs nearly $60 \%$ of the workforce (GSS, 2011)

Although a largely agrarian economy, Ghana is $51 \%$ self-sufficient in cereal production. Rice self-sufficiency was estimated at $30 \%$ in 2009 (Asare, 2010). From the national perspective, Ghana is a food secure nation (WFP, 2007b). However, lack of physical and economic access to food is perhaps the largest contributor to household food insecurity in many rural and urban poor households. Despite progress towards achieving food security, hunger is still prevalent in Ghana. The government's poverty reduction strategy paper identifies low productivity and poorly functioning markets as the major causes of rural poverty (IFAD, 2009).

Home-Grown School Feeding (HGSF) is an intervention by many developing countries including Ghana to reduce poverty, hunger and malnutrition, and food insecurity overall, especially among children. The HGSF programme provides food produced and purchased within a country to school children. In the view of Tomlinson (2007), HGSF aims to reach 50 million children of school age worldwide by 2015 and according to NEPAD (2005b), if 50 million children were fed for 220 days a year, 5 million tons of food per year would be consumed, which would require the produce of at least 2 million poor farmers.

Ghana has a long history of school feeding programmes implemented by different development agencies, particularly in the north of the country. Fisher, (2007) reported that the Catholic Relief Services and the World Food Programme have been active in school feeding programmes in Ghana since 1958 and late 1960s respectively. The Ghana School Feeding Programme which was launched in 2005 was basically intended to stimulate the local 
economy through creation of additional demand for local farm produce, and to improve food security. This objective aligns closely with the United Nations' Millennium Development Goals (MDGs) on hunger and poverty

The programme is independently implemented by the Government of Ghana except in the three northern regions (Northern, Upper East and Upper West), where some primary school children receive food through joint programming with the World Food Programme.

Rice constitutes a major staple on GSFP menu. It is normally cooked 3 times a week for the pupils. Based on the objectives of Programme of reducing malnutrition and boosting domestic food production among others, the study focused on how procurement of rice domestically could impact on local output. The rice grown in the country especially in the north (more of it being brown rice) provides more nutrition than foreign white rice. Local rice (especially brown rice) has been reported to be nutritionally better than foreign (white rice). Brown rice provides more fiber and naturally occurring vitamins and minerals than white rice. Brown rice contains antioxidants. It also contains important vitamins such as vitamin $B$, folic acid, niacin and riboflavin. These vitamins help the body use the energy provided by the foods we eat, as well as helping it use dietary protein to build and maintain cells and tissue ${ }^{1}$. People who consume five or more servings of white rice every week had a greater risk of developing type 2 diabetes $^{2}$.

Malnutrition is both a cause and consequence of poverty. Malnutrition remains a pervasive problem spreading through urban communities in Ghana. The most important form of malnutrition is Protein-Energy Malnutrition (PEM) which specifies the lack of enough protein from meat and other sources (World Bank, 2011).

According to a UN Development Assistance Framework (UNDAF) for Ghana 2006-2010, there has also been an increase in child malnutrition in all regions of Ghana between 2006 and 2010. In the three northern regions the report showed that, the proportion of underweight children under five years is much higher, ranging from $34 \%$ to $38 \%$. In general rural children are twice as stunted (30\%) as urban children.

From these reports it is not surprising that

\footnotetext{
${ }^{1}$ See Ohio State University online nutrition column

${ }^{2}$ See: www.livistrong.com on nutrition from beans and rice
}

the government has in recent years been making frantic efforts to address malnutrition among children in Ghana. One of the major policy interventions is the Ghana School Feeding Programme. This intervention perhaps is most laudable as beneficiary children are mostly from rural communities where the malnutrition prevalence rates are high. Though not an exact agricultural policy, its potential impact on both malnutrition and food security and has been clearly highlighted in the programme document. Thus the government of Ghana has over the years pursued significant policies intended to tackle the problem of malnutrition and food insecurity in the country. Despite the moderate progress made in recent years, these problems still persist in the country especially in the north.

Generally, School Feeding Programmes in Ghana had seen considerable investment in the local economy since 2005. In 2006 for example, the World Food Programme (WFP) paid about US\$549,376 to local contractors for supplying food for school feeding. It was also expected to source $100 \%$ of its food procurement needs locally which was estimated to be US\$1.9 million for 2007, US\$1.9 million for 2008, US\$2.3 million for 2009 and US\$1.6 million for 2010. It is further estimated that $90 \%$ of this value will be bought from small-scale farmers. With these kinds of investment, the expectation that domestic food production will increase is therefore not out of place. However, the GSFP has little impact in boosting domestic food production. This is mainly due to challenges regarding procurement processes.

Following these investment, however, the educational portfolio of the GSFP has made relatively great strides as compared to the agricultural portfolio of the programme. Seven years after the inception of the programme, enrolment, attendance and retention have improved remarkably in most beneficiary schools.

PCD (2010) developed a sustainable model to link farmers and caterers in GSFP. In the model, the challenges faced by farmers and caterers were presented and analysed through value chain frameworks and the participation of stakeholders. They identified the mismatch of incentives ${ }^{3}$ of farmers and caterers which prevent their integration in the GSFP value chain.

${ }^{3}$ Cash flow, lack of trust between farmers and caterers and difficulty of farmers accessibility 


\section{Objective of paper}

The main objective of this paper is therefore to determine rice farmers' accessibility to the Ghana School Feeding Programme and its effect on production in the Tamale metropolis, Tolon-Kumbungu and Karaga districts of the northern region of Ghana and the specific objectives are; (i) to determine rice farmers accessibility to the programme. (ii) to analyse the effect of access to the programme on rice output and yield and (iii) to determine how the rice value chain facilitates procurement by the School Feeding Programme

\section{The Ghana School Feeding Programme (GSFP) concept}

The Ghana School Feeding Programme's objective to reduce poverty and food insecurity is anchored on the following conceptual framework:

1. Long term community food security among poor rural households is the ultimate objective. The strategy to feed school children with locally prepared food that is nutritionally adequate will focus on spending on local foodstuffs. This is expected to provide ready market for farm output, leading to wealth creation at the rural household and community level. This will help rural communities to generate wealth through improved incomes from the ready market for their farm output (as provided by the school feeding programme).

2. With improved incomes, poor rural households can afford the additional food intake needed to ensure the full complement of nutritional needs that will address the rampant short-term hunger, and the problems of malnutrition.

3. Importantly, it is expected that this strategy will be supported by the spending of about $80 \%$ of the feeding cost in the local economy, particularly in the community of the school, or in the district as a whole for the direct sourcing of the programme's inputs.

Figure 1 illustrates the possible impacts of the Ghana School Feeding Programme as an intervention to reduce hunger and malnutrition using locally produced foods. As illustrated, there are 3 main outcomes of the GSFP, namely; increased demand for locally produced foods, increased school enrolment and increased nutrient intake of school children. The first box on the top left corner of the diagram represents the basic idea of the Ghana School Feeding programme. Boxes with broken lines specifically illustrate the programme's impact on education, the boxes with single line represents its impact on the nutrition and health of school children, while the boxes with double lines illustrate the impact on agriculture.

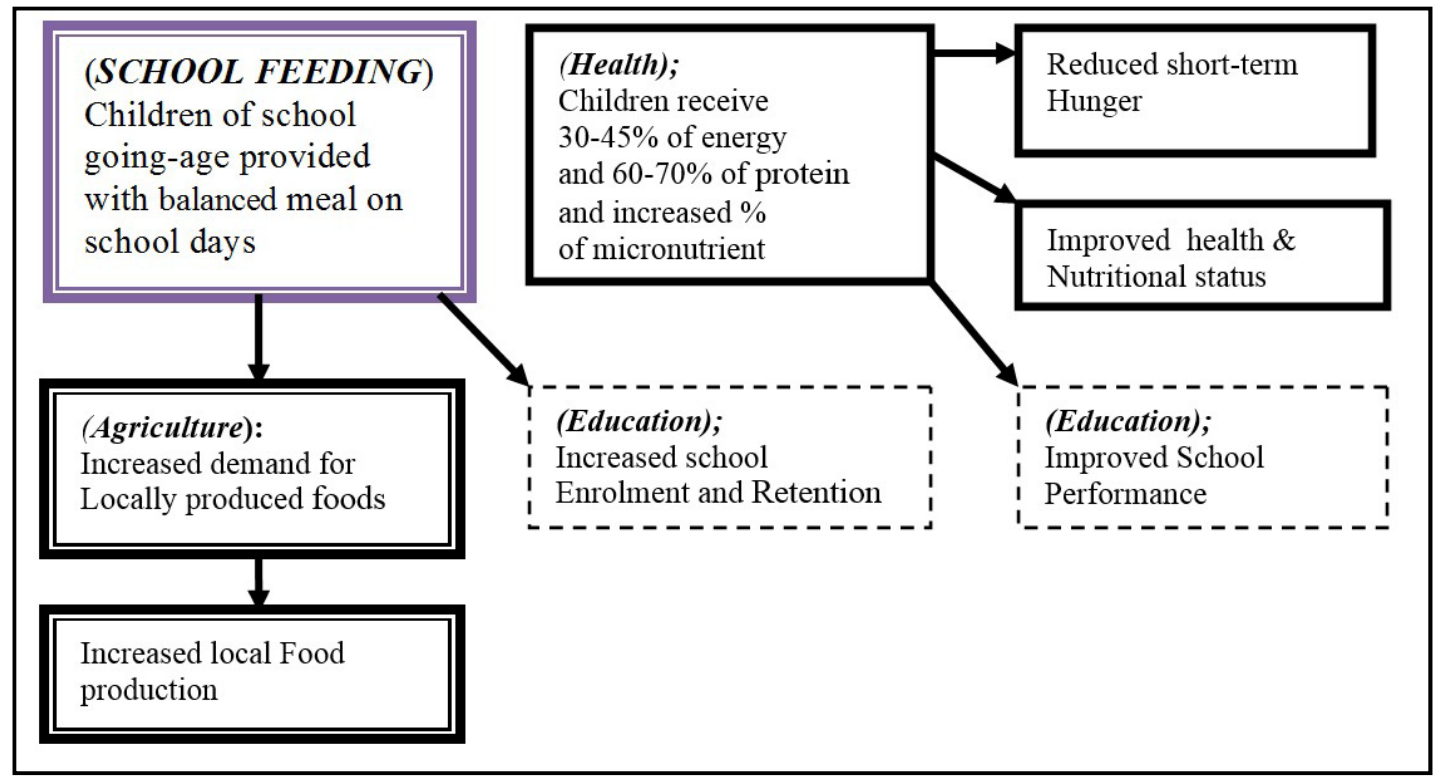

Source: Adapted from NEPAD, (2005b)

Figure 1: Conceptual framework of school feeding interventions. 


\section{Materials and methods}

A combination of analytical tools was used in the study. These include descriptive statistics, t-test, and econometric regression model. A total of 100 small holder rice farmers and 90 individual players ${ }^{4}$ in the rice supply chain of the school feeding model were sampled across the three districts using a combination of purposive and simple random sampling techniques. That is targeting the population living in communities where the GSFP was being implemented. Both the farmers and the actors in the rice supply chain were interviewed using structured questionnaires.

In analyzing farmers' accessibility to the GSFP market, descriptive statistics were used and farmers were categorized into those who have had access to GSFP market either directly or indirectly through local millers and those who have not. The number of farmers in respect of each group was identified. Frequency tables cross tabulation were used to analyse the data. Farmers accessibility were measured using variables such as, farmers' awareness of GSFP programme, farmers living in GSFP Community, farmers' direct sales of paddy rice to caterers, the number offers made and the proportion of local rice purchased by the school caterers.

In determining the effect of the Programme on output of rice farmers in the study area, we used the Independent t-test to compare the mean output and yield across three different groups of 100 sampled farmers in 2011. The three categories include farmers who have direct access to GSFP, those who have indirect access and those who have no access. The transcendental logarithmic production function was used to further investigate whether access to GSFP (direct or indirect) had any significant effect on output.

The transcendental logarithmic production function commonly referred to as the translog function, is an attractive and flexible function. This function has both linear and quadratic terms with the ability of using more than two factor inputs. Its flexibility circumvents the problem of over restrictions and allows a more general specification of the model since it can represent any underlying arbitrary structure of production at any point. Moreover, the translog function relates output to inputs

${ }^{4}$ Local millers, wholesalers, and retailers and can be augmented with socioeconomic ${ }^{5}$ and demographic variables. It allows the introduction of a dummy variable to capture the difference in production or productivity between two groups of farmers.

The translog has therefore been widely applied in empirical analysis. For instance it has been used to examine input substitution, technical change and productivity growth, and production efficiency. Tzouvelekas, (2000) Cites Berndt and Christensen (1973); May and Denny (1979); Greene (1980) and Kalirajan (1990) as having applied this model. In their study on 'A Stochastic Production Investigation of Fish Farms in Ghana Onumah and Acquah (2011) used the stochastic production frontier approach to analyse the technical efficiency and its determinants of fish farms in Ghana using a cross-section data. The study considered the explicit effects of family and hired labour on production by setting the log-value of the zero-observation of these two sources of labour to zero with dummy variables. Thus this approach though focused on technical efficiency can also be useful in assessing the effect of School Feeding Programmes on the output of farmers using farmers' access to the market created by the programme as a dummy variable as opposed to Cobb Douglas Production model.

The Cobb Douglas model is strongly criticized on the following; its accuracy in different industries and time periods (Stewart 2008), for analysis of policies affecting factor returns such as taxes on capital and labor income, the Cobb-Douglas specification may be too restrictive (Antras 2004). More so it was developed because it had attractive mathematical characteristics, and concentrated so much on diminishing marginal returns to capital and labour as key factors of production. Empirical study by Krishnapillai and Thompson (2012) indicate that the translog production function is preferred when analysis are made using cross sectional data ${ }^{6}$.

\section{Model specification}

In a simplified analysis, the function can be approximated by second order Taylor series as originally specified by Christensen et al. (1973). In this case a three-input translog production function can be written in terms of logarithms as:

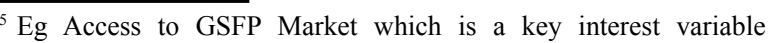
in the study

${ }^{6}$ Cross sectional data was used in this study
} 


$$
\begin{aligned}
\ln Q & =\alpha 0+\beta K \ln K+\beta L \ln L+\beta M \ln M \\
& +1 / 2 \beta K K \ln K 2+\beta K L \ln K \ln L \\
& +\beta K M \ln K \ln M \frac{1}{2} \beta L L \ln L 2 \\
& +\beta L M \ln L \ln M+1 / 2 \beta M M \ln M 2+\mu
\end{aligned}
$$

Where $Q=$ output variable, $\alpha=$ constant term, $\beta=$ coefficients of variables to be measured, $K, L, M=$ input variables, $\mu=$ error term.

The use of this model in analysing the effect of the Ghana School Feeding Programme on output of rice following this review is therefore justified. The empirical tranlog model for the study is given as:

$$
\begin{aligned}
\operatorname{Ln}(Y) & =a_{0}+a_{1} \operatorname{Ln}\left(X_{1}\right)+\ldots . .+a_{6}+\operatorname{Ln}\left(X_{0}\right) \\
& +0.5\left[\operatorname{Ln}\left(X_{1}\right)^{2}+\ldots \ldots .+a_{6} \operatorname{Ln}\left(X_{0}\right)^{2}\right] \\
& +a_{12} \operatorname{Ln}\left(X_{1}\right) \operatorname{Ln}\left(X_{2}\right)+\ldots . . \\
& +a_{16} \operatorname{Ln}\left(X_{1}\right) \operatorname{Ln}\left(X_{0}\right)+a_{7} X_{7}+\varepsilon
\end{aligned}
$$

Where $Y=$ rice output (explained variable). The explanatory variables are $X_{1}=$ insecticide usage, $X_{2}=$ farm labour, $X_{3}=$ total farm size, $X_{4}=$ age of farmer, $X_{5}=$ fertilizer application, $X_{6}=$ extension visits, $X_{7}=$ access to GSFP, and $\varepsilon=$ error term.

\section{Estimation procedures}

Quantity of rice output (Y): The volume of production of rice which is an explained variable is measured in $\mathrm{kg}$. Rice farmers output was estimated using total rice harvest in 2011 season. Farmers could not provide standard unit of measurement. Data indicated quantity of rice in bags (cocoa sacks) which was converted in $\mathrm{kg}$ using standard scale measure.

\section{Independent variables}

The translog is a production function which relates output to inputs. In addition the model can be augmented with socioeconomic and demographic variables. The following are hypothesized to influence farmers' output.

Insecticide usage $\left(\boldsymbol{X}_{\boldsymbol{l}}\right)$ : This is a continuous variable measured in litres. Farmers were asked to provide data on litres of insecticides applied to their rice farms. The a priori expectation of the effect of insecticide on production is mixed. Tremendous benefits have been derived from the use of pesticides in forestry, public health and the domestic sphere and, of course, in agriculture (Wasim et al. 2009). However, pesticides may cause damage to the soil and non-target plants if not properly applied. In the view of Glotfelty and Schomburg (1989), some pesticide drift occurs during every application, even from ground equipment. This perhaps is the negative side of insecticides usage which may also affect output.

Farm Labour $\left(\boldsymbol{X}_{2}\right)$ : It is a continuous variable, measured in man-days. Farm labour in this study comprises both family and hired labour. The study used the total number of labour man-days used by sampled rice farmers. This variable could have a positive or negative influence on farmers' output. As farmers have access to more labour, the interest to expand farm size would increase. Increases in labour productivity were achieved without a substantial increase in output per unit of land from the mid 5 th through the $18^{\text {th }}$ centuries in the English agriculture thus showing a positive effect of farm labour on output (Apostolides et al., 2008). This suggests that the more man-days of farm labour a farmer uses, the more output he could get from the farm cetris paribus. However in analysing production in the short run, the law of diminishing returns could have a negative farm labour effect on output as land is a fixed input.

Total farm size $\left(X_{3}\right)$ : The total size of rice farm land owned by a farmer is among the variables that could influence both output and supply. It is a continuous variable, measured in hectares and is expected to influence output positively. Data on farm size was recorded in acres but later converted to hectares.

Age of farmer $\left(\boldsymbol{X}_{4}\right)$ : Age is a continuous variable and measured in years. The expected influence of age is assumed positive or negative taking the presumption that as farmers get older they could acquire skills and hence produce more. It is also a proxy measure of farming experience. Tshiunza et al. (2001) found in Nigeria that younger farmers tended to produce and sell more bananas for market than older farmers thus an indication of a negative relationship between age of farmer and output.

Fertilizer application $\left(\boldsymbol{X}_{5}\right)$ : This is also a continuous variable measured in kilograms and the apriori expectation is positive. This represents the total quantity of fertilizer applied by farmers to their rice farms during the year under consideration. As the farmer applies more fertiliser to his rice field, it is expected that farm yield will increase. Crop yields have increased substantially in many parts of the world which have been attributed to a combination of factors including increased used of mineral fertilizers.

Extension visits $\left(\boldsymbol{X}_{\boldsymbol{\sigma}}\right)$ : This is a continuous variable measured as the number of extension visits farmers 
got from extension officers in a season. This variable is expected to influence output and supply of rice positively. Obviously, as farmers learned more they would produce more and supply or participate more in a market provided the knowledge acquired is effectively utilised.

Access to a GSFP market $\left(\boldsymbol{X}_{7}\right)$ : This is a dummy variable with a value of 1 for farmers who had access to the GSFP market and 0 for those who did not. Access here has been defined at two levels; farmers who sold their paddy rice directly to GSFP and those who sold through local millers. This variable is therefore estimated using the combined effect of direct and indirect access to the GSFP market. This was necessitated by the fact that paddy rice is a raw material which requires processing before consumption and this emphasizes the role of other players in the value chain. The survey data on the rice value chain analysis indicate that the local miller is an import intermediary between the rice farmer and the GSFP caterer. The a priori expectation for this variable is positive. As farmers have access to the market created by the GSFP, their output will increase.

The summary of variables definitions and a priori expectation is presented in Table 1 below.

\section{The rice supply chain and GSFP procurement}

A supply chain is a network of facilities that procure raw materials, transform them into intermediate goods and then final products, and deliver the products to customers through a distribution system. This system may include a physical person such as a farmer, a trader or a consumer, as well as legal entities such as a business.

In this section descriptive statistics was employed to analyse the rice commodity chain. The analysis was based on quantitative and qualitative flow among key actors such as rice farmers, GSFP caterers, local millers, retailers and wholesalers. Using a cross section data, the output of rice farmers was computed. At farm gate level, quantity of rice used for personal consumption by the farmer was estimated. The quantity of paddy rice purchased at farm gate by the local millers, GSFP caterers, retailers and wholesalers were also computed alongside the price levels. The quantity flow of milled rice between local millers, GSFP caterers, wholesalers and retailers was also analysed. In this regard pictorial description of the players, their roles and relationships and how each facilitates procurement by the GSFP is presented. Using a cross section data in 2011, the relationship between GSFP rice consumption and the cost of procurement from the various sources of supply have been also been analysed

\section{The study area}

The Northern Region is the largest land area of Ghana. It has a land size of 70,383sq $\mathrm{km}$ representing $29.51 \%$ of total land area in the country. As of 2011, the region was made up of 20 districts. The total labour force in the region is also estimated as 727,553 with $71.2 \%$ of this number engaged in agriculture (GSS 2011). The figures of the 2010 Ghana Population and Housing Census puts the population of the region at about 2,479,461 representing about $10.1 \%$ of the national total (GSS 2012).

The study was conducted in the Tamale metropolis, Tolon-Kumbungu ${ }^{7}$ and Karaga districts of the Northern region of Ghana. The study considered two main factors; first, the number of pupils fed by the programme and second, the areas that rice is mostly grown. Additionally Tolon-Kumbungu in particular has been a pilot district for the GSFP. According to the World Food Programme monthly bulletin for November 2010,

${ }^{7}$ Now two districts - Tolon and Kumbungu districts

\begin{tabular}{lllc}
\hline Explanatory variables & Definition & A priori expectation \\
\hline Insecticides & $\left(X_{1}\right)$ & Litres of insecticides used & + \\
Farm labour & $\left(X_{2}\right)$ & Man days of total labour services & + \\
Farm size & $\left(X_{3}\right)$ & Farm size in hectors (ha) & + \\
Age of farmer & $\left(X_{4}\right)$ & Age of farmer in years & $+/-$ \\
Fertilizer usage & $\left(X_{5}\right)$ & Kilograms of fertilizer used & + \\
Extension visits & $\left(X_{6}\right)$ & Extension visits in numbers & + \\
Access to GSFP & $\left(X_{7}\right)$ & Access to GSFP (Yes = 1, No $=0)$ & + \\
\hline Farm output $(Y)=$ explained variable measured in kilograms & \\
Source: own processing & \\
\multicolumn{5}{c}{ Table 1: Summary of variables definitions and a priori expectation. }
\end{tabular}


it was the only district that recorded a $45 \%$ increase in rice production over the year 2009 output (WFP, 2010). Tamale metropolis also had the highest number of pupils enrolled in schools under the programme with an estimated $13.5 \%$ of the 50,597 pupils benefitting in the entire region ${ }^{8}$ as at the year 2011 .

In Tamale metropolis it is estimated that about $60 \%$ of the people are engaged in agriculture. The major crops cultivated are maize, rice, sorghum, millet, cowpea, groundnuts, soya bean, yam and cassava. Farmers in the Metropolis and rural Tamale in particular are small holder subsistence food producers with few income earning opportunities largely due to low productivity, lack of off-farm employment and vulnerability to natural calamities such as unreliable rainfall and bush fires (MoFA, 2011). Total land holders in the metropolis in 2006 were 33,614 of which 23,018 holders representing $68 \%$ were producing rice (Seidu 2008). Low productivity and marketing of farm produce are the most prominent challenges in the agricultural sector in the metropolis.

Tolon/Kumbungu District is one of the districts created by the erstwhile Provisional National Defence Council (PNDC) Law 207 in 1988 with Tolon as its Capital. The district was carved out of the then West Dagomba District Council (WDDC). It covers an area of about 2,741 square kilometres and forms about $3.9 \%$ of the total land size of the northern region. The district shares borders with the West Mamprusi District to the north, West and Central Gonja districts to the west and south respectively and with the Savelugu-Nanton District and Tamale metropolis to the east.

\section{Results and discussion}

Farmers' accessibility to the Ghana School Feeding Programme

From the literature there seem to be no clear guidelines regarding how caterers should buy foodstuffs from the farmers. Caterers are asked to buy local foodstuffs from farmers living in the communities where the GSFP is being run. To facilitate farmers accessibility to the GSFP market more easily a GSFP procurement manual could have been designed detailing the procedure and information of farmers including their farm activities in the communities. Farmers who sell paddy rice to the GSFP caterers were identified

${ }^{8}$ GSFP statistics 2011 by asking them if they were aware of the school feeding programme and whether caterers have been buying rice from them directly or through middlemen such as local millers, retailers/market women or wholesalers.

Feeding of the children is happening on a daily basis in the schools visited. However, most of foodstuffs especially rice are not purchased from local farmers but from local millers and from the market. From the table for example only $17 \%$ of rice farmers sell their paddy rice to caterers while $34 \%$ sell through local millers. From the study, farmers are within the reach of the GSFP and it would not be difficult if the programme really intends to source foodstuff from the communities where the GSFP schools are located. This is because $83 \%$ of the rice farmers are in the communities where the programme is being implemented while about $87 \%$ of them are aware of the existence of the programme. Accessibility is therefore not a serious challenge. With only $17 \%$ of farmers supplying directly to the programme it means that GSFP caterers are not making offers to the rice farmers.

From table 2, caterers buy more directly from farmers in Karaga and Tolon/Kumbungu districts than they do in Tamale metropolis. The table shows that about $94 \%$ of the rice farmers who sell directly to the GSFP caterers said the caterers do not have any selection criteria for buying from them and only $6 \%$ said they buy from them because they live in the communities where the GSFP is being run. This clearly indicates that selection of farmers is arbitrary. There are no clear guidelines regarding the purchase of foodstuffs from the farmers. This could be attributed to the nature of the supply chain in the various districts. It is easier for caterers to locate farmers in these two districts than it is in the Tamale metropolis. Most of the caterers are residents of the communities where GSFP is being implemented in the two districts than they do in Tamale metropolis. For example about 100\% of the sampled farmers interviewed from both Tolon-Kumbungu and Karaga districts are residents of GSFP Communities. The caterers did not have any selection criteria for purchasing rice from $64.5 \%$ of the farmers who sold directly to the GSFP (11 respondents out of 17) while $34.2 \%$ (6 respondents out of 17) from whom they bought the rice lived in the communities where the GSFP is being implemented. This clearly indicates that selection of farmers is arbitrary. There are no clear guidelines regarding the purchase of foodstuffs 


\begin{tabular}{|c|c|c|c|c|c|}
\hline Level of Accessibility & & $\begin{array}{c}\text { Tamale } \\
\text { metropolis }\end{array}$ & $\begin{array}{c}\text { Tolon/ } \\
\text { Kumbungu }\end{array}$ & Karaga & Total \\
\hline \multirow{3}{*}{$\begin{array}{l}\text { Resident in GSFP } \\
\text { community }\end{array}$} & Yes & 47 & 20 & 20 & 87 \\
\hline & No & 13 & 0 & 0 & 13 \\
\hline & Total & 60 & 20 & 20 & 100 \\
\hline \multirow[t]{3}{*}{ Awareness of GSFP } & Yes & 48 & 19 & 20 & 87 \\
\hline & No & 12 & 1 & 0 & 13 \\
\hline & Total & 60 & 20 & 20 & 100 \\
\hline \multirow[t]{3}{*}{ Direct access } & No & 52 & 16 & 15 & 83 \\
\hline & Yes & 8 & 4 & 5 & 17 \\
\hline & Total & 60 & 20 & 20 & 100 \\
\hline \multirow[t]{3}{*}{ Selection criteria } & Prox. to Sch & 0 & 3 & 3 & 6 \\
\hline & No Criteria & 3 & 5 & 3 & 11 \\
\hline & Total & 3 & 8 & 7 & 17 \\
\hline \multirow[t]{4}{*}{ Access via local miller } & No & 15 & 6 & 2 & 23 \\
\hline & Yes & 17 & 7 & 10 & 34 \\
\hline & I don't Know & 28 & 7 & 8 & 43 \\
\hline & Total & 60 & 20 & 20 & 100 \\
\hline
\end{tabular}

Source: from survey data December 2011. $\mathrm{N}=100$

Table 2: Farmer accessibility to the GSFP by district ( $\%$ of farmers).

from the farmers. For analytical purposes however, farmers' accessibility in general including those who sold their rice produce to the GSFP caterers through local millers is significant ${ }^{9}$.

\section{Effect of GSFP procurement on output of rice farmers}

To analyse the effect of the Ghana School Feeding Programme on output and yield of rice farmers, the t-test statistics was initially used to see if there was any significant difference between participants and non-participants in the GSFP market followed by a regression using the translog model to find out whether access to GSFP had a significant effect on rice output. The results are presented in tables 3 , 4 and 5 below.

The rice farmers were initially categorized into two groups; those who have been selling rice to GSFP either directly or indirectly (51\%) and those who do not sell to them (49\%). Firstly, we conducted t-test to see if there were any significant differences in rice output and yield among the two categories of farmers. Secondly a comparison was made between those selling directly and indirectly to the GSFP. The results of the t-test are presented in tables 3 and 4 while that of the translog model is presented in table 5. From the tables, the average output of farmers who sold rice to the caterers (directly or indirectly) was marginally higher than

\footnotetext{
${ }^{9}$ Direct access $=17 \%$, access via local miller $=34 \%$ a cumulative of $51 \%$
}

those who did not sell. However in terms of yield, those who did not have access to the programme had a slightly higher rice yield relative to farmers who had access (see table 3). Also the average output and yield of farmers who had direct access to the programme were relatively higher than those who had indirect access (see table 4). The differences in each of the above cases were however not statistically significant.

Table 5 presents the regression results for the transcendental logarithmic production function. The R-squared value of 0.9235 implies that, about $92.4 \%$ of the variations in the dependent variable are explained by the variations in the independent variables. The F-statistic value of 388.5 shows the fitness of the model which explains the explanatory power of all the independent variables put together on the dependent variable. This is significant at $1 \%$.

From the table all the variables are statistically significant with the exception of insecticides, age, extension visits and access to Ghana School Feeding Programme. The variables that met the a priori expectations are farm labour (significant at 10\%), farm size and fertilizer application (both significant at $1 \%$ ). Farmer access to GSFP has positive effect on rice output. Farmers who had access to the Programme had 3 percent more output than those who do not but this margin of a difference is not statistically significant. 


\begin{tabular}{lccccccc}
\hline Test variable & Access & $\mathrm{N}$ & $\begin{array}{c}\text { Mean } \\
(000)\end{array}$ & $\begin{array}{c}\text { Std. } \\
\text { deviation }\end{array}$ & $\begin{array}{c}\text { Std. } \\
\text { error }\end{array}$ & $\begin{array}{c}\text { Mean } \\
\text { difference }\end{array}$ & $\begin{array}{c}\text { Sig } \\
\text { (2-tailed) }\end{array}$ \\
\hline Output & Yes & 51 & 5.370 & 4682.895 & 668.985 & 1170.580 & 0.337 \\
(tons) & No & 49 & 4.199 & 7134.392 & 999.015 & - & 0.333 \\
Yield & Yes & 51 & 1.482 & 832.291 & 118.899 & -122.086 & 0.632 \\
Kg/ha & No & 49 & 1.604 & 1578.337 & 221.011 & & 0.628 \\
\hline
\end{tabular}

Source: survey data 2012

Table 3: Output and yield differences for access and no access to GSFP market $(\mathrm{N}=100)$.

\begin{tabular}{lccccccc}
\hline Test variable & & $\mathrm{N}$ & $\begin{array}{c}\text { Mean } \\
(000)\end{array}$ & $\begin{array}{c}\text { Std. } \\
\text { deviation }\end{array}$ & $\begin{array}{c}\text { Std. } \\
\text { error mean }\end{array}$ & $\begin{array}{c}\text { Mean } \\
\text { difference }\end{array}$ & $\begin{array}{c}\text { Sig } \\
\text { (2-tailed) }\end{array}$ \\
\hline Output (kg) & Direct & 17 & 7.012 & 11648.963 & 2825.289 & 1219.824 & 0.345 \\
& Indirect & 34 & 5.793 & 2283.59 & 391.632 & - & 0.158 \\
Yield (kg/ha) & Direct & 17 & 2.704 & 2355.74 & 571.351 & 649.629 & 0.894 \\
& Indirect & 34 & 2.055 & 387.748 & 66.498 & - & 0.311 \\
\hline
\end{tabular}

Source: survey data 2012

Table 4: Output and yield differences for direct and indirect access to GSFP market $(\mathrm{N}=51)$.

\begin{tabular}{|c|c|c|c|c|}
\hline Variable & Coefficients & Std err & t-value & P-value \\
\hline Constant & - & 0.042 & 0.29 & 0.772 \\
\hline lnInsecticides & 0.202 & 0.228 & 1.11 & 0.273 \\
\hline lnlabour & $0.059 * *$ & 0.071 & 2.29 & 0.025 \\
\hline lnFarm size & $0.585 * * *$ & 0.254 & 2.84 & 0.006 \\
\hline lnAge & 0.048 & 0.218 & 1.59 & 0.117 \\
\hline $\operatorname{lnFertilizer}$ & $0.012 * * *$ & 0.118 & 0.12 & 0.007 \\
\hline $\operatorname{lnExt}$ visits & -0.115 & 0.118 & -2.8 & 0.903 \\
\hline Access to GSFP & 0.029 & 0.037 & 2.49 & 0.215 \\
\hline \multicolumn{3}{|c|}{$* * *$ significant at $1 \%$ level } & \multicolumn{2}{|c|}{ Sample size $=100$} \\
\hline \multicolumn{5}{|c|}{$* *$ significant at $5 \%$ level $\mathrm{R}$-square $=0.72$} \\
\hline \multicolumn{3}{|c|}{ F-statistic $(28,71)=388.50$} & \multicolumn{2}{|c|}{ Prob $F=0.000$} \\
\hline \multicolumn{5}{|c|}{ Dependable Variable: Rice output measured in kg } \\
\hline
\end{tabular}

Table 5: Regression results explaining rice output.

Rice supply chain assessment and GSFP procurement

Descriptive statistics were used to analyse the rice supply chain and GSFP procurement. Actors in the School Feeding model supply chain were identified. Table 6 illustrates the frequencies of the various sources of rice supply to the caterers. The local miller is the GSFP caterers' major source of rice supply followed by a combination of farm gate and local miller, the retailer/market queen. The farmer/farm gate and the wholesaler being the least sources of supply.

\begin{tabular}{lcc}
\hline Supplier & Frequency & Percent \\
\hline Local Miller & 20 & 40 \\
Retailers & 10 & 20 \\
Farm gate and local miller & 11 & 22 \\
Farm gate only & 6 & 12 \\
Wholesaler & 3 & 6 \\
Total & 50 & 100 \\
\hline
\end{tabular}

Source: author's computation from survey data December 2012

Table 6: GSFP caterers' sources of rice supply. 
Actors in the rice supply chain (the school feeding model)

The key actors in the rice supply chain in the model of school feeding in Ghana include rice farmers, GSFP caterers, local millers and market women who are mostly retailers. Analysis of the supply chain is presented in figure 1. Structured questionnaires were used to interview 190 respondents, made up of 100 rice farmers, 50 GSFP caterers, 22 local millers, 11 retailers and 7 wholesalers.

Figure 2 illustrates the pattern of rice flow from farmers to local millers, through to GSFP caterers, wholesalers and retailers or market queens. The boxes with broken lines represent quantities of milled and paddy rice based on 2011 estimates. The GSFP caterer is at the centre of the chain buying both paddy and milled rice from the farmer and the rest of the actors respectively. From the survey data all the actors in the chain with the exception of the retailers who sold only milled rice got their supplies from the farmer. The deep arrows show the principal sources of supply of paddy and milled rice for the GSFP caterer and the local miller. The survey data illustrated in table 5 suggest that about 40 percent of caterers buy from local millers. The light arrows show an interaction between the local miller, the retailer and the wholesaler. Milled rice is supplied from the local miller to the retailer and the wholesaler. The retailer also gets his/her supplies from the wholesaler and there is also a flow of paddy rice from the farmer to the wholesaler. As can be seen, majority of the local millers draw their paddy rice supplies from the farmer.

The average prices of paddy and milled rice have also been appropriately shown in the chain. The farm gate price of paddy is GHC 45.00 per bag $(80 \mathrm{~kg})$ and the wholesale price is GHC50.00. After processing, a bag of milled rice $(120 \mathrm{~kg})$ is sold by the local miller at GHC130.00 while the same quantity is being sold by the wholesaler and the retailer at GHC 140.00 and GHC 150.00 respectively

\section{Conclusion}

Rice farmers across the study districts do not have direct access to the Ghana School Feeding Programme as more GSFP caterers buy milled rice from local millers than paddy rice. This is largely due to the fact that majority of the caterers have other jobs aside the catering services and therefore do not have enough time to process paddy rice which they can easily purchased from the farmers. Another factor that hinders farmers' accessibility to the GSFP market is delays in the release of feeding bursaries to caterers.

Selling to the Ghana School Feeding Programme

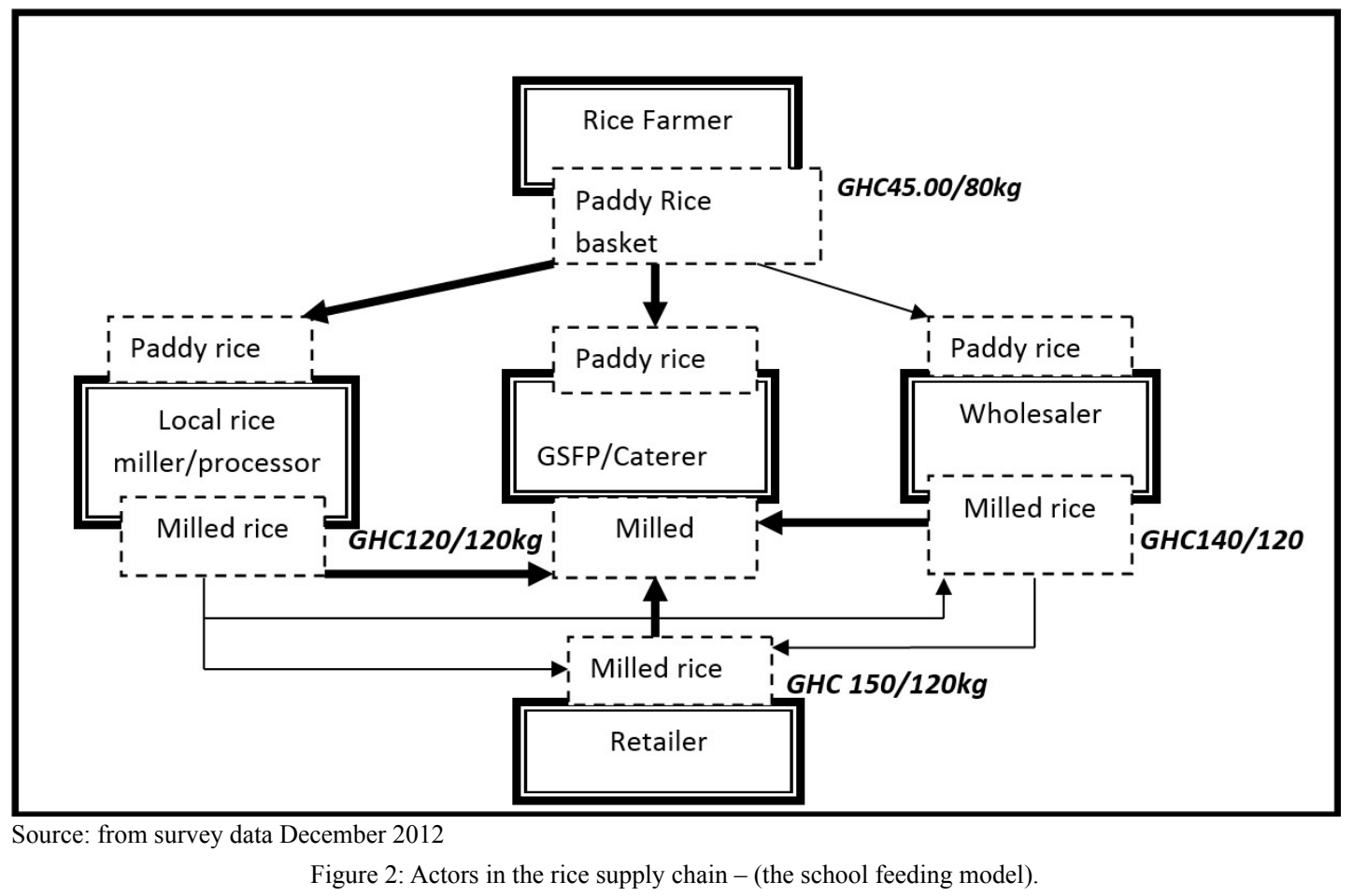


does not enhance farmer's yield or output because farmers are not directly linked to programme. The rice value chain does not facilitate GSFP procurement from local farmers because farmers do not process paddy into milled rice, a product used by caterers. Caterers have other jobs and prefer not to add rice milling to their income generation portfolios.

The recommendations are direct measures that can be executed to strengthen the relation between farmers and caterers, increase local purchase and make the situation for the market relation between caterers and farmers more favourable.

In order to facilitate easy farmers' access to GSFP market therefore, the GSFP secretariat and government for that matter should contract caterers on permanent basis focusing on those who can spend enough time and energy to buy local foodstuffs including paddy rice directly from farmers. The disbursement of feeding bursaries should also be timely such that it coincides with the rice harvest periods. In this regard, it may also be possible for the government to assist caterers to obtain loans from banks in order to meet their demand schedules.

Government should support rice farmers by creating the necessary environment to make accessibility to the GSFP market more easily. This can be done by enlisting all farmers in the GSFP communities across the countries and their details submitted to caterers. A procurement manual detailing the procurement processes which must focus on buying foodstuffs from farmers should also be initiated and a monitoring system developed to check compliance. The target farmers can be supported with credit facilities, fertilizer subsidy and other inputs to help increase their output and yield.

The GSFP Supply chain can be shortened if caterers buy rice directly from the farmers. This can be possible if government in collaboration with the Ghana Education Service provides adequate storage facilities in all GSFP schools. With this, caterers will not have much problem stocking paddy rice which they can buy from farmers. The list of all rice farmers in GSFP communities will assist caterers to locate farmers easily. From the literature, caterers are assisted by cooks to provide food for the pupils. It is therefore possible for a caterer to handle more than a school so as to increase the number of pupils under her control to enable her order large quantity of rice from the farmer.

Corresponding author:

Abdul-Fatawu Shaibu

Department of Agricultural Economics and Agribusiness, University of Ghana

P. O. Box LG 25, Legon Accra, Ghana

E-mail:fatash73@yahoo.ca

\section{References}

[1] Antras, P. Is the U. S. Aggregate Production Function Cobb-Douglas? New Estimates of the Elasticity of Substitution. The Berkeley Electronic Press (bepress). 2004. [Online] Available: http://www.bepress.com/bejm [Accessed: 25 Sept 2014].

[2] Apostolides, A. Stephen B., Bruce, C, Mark, O., and van Leeuwen, B. English Gross Domestic Product, 1300-1700: Some Preliminary Estimates. 2008. [Online] Available: www2.warwick.ac.uk/fac/soc/economics [Accessed: 22 Febr 2012].

[3] Asare, O., Yaw, B. Mapping of Poverty Reductions Strategy Papers. Sector Strategies and Policies related to rice development in Ghana. Coalition for Africa Rice Development (CARD), C/o AGRANairobi, Kenya $15^{\text {th }}$ October 2010.

[4] Christensen, L., Jorgenson, D., and Lau, L. Transcendental Logarithmic Production Frontiers, The Review of Economics and Statistics, February 1973, p. 28-45.

[5] Fisher, E. A Desk Review of the Ghana School Feeding Programme. Centre for Development Studies University of Swansea, United Kingdom. 2007.

[6] Ghana Statistical Service. Gross Domestic Product 2011. Ghana Statistical Service National Accounts and Economic Indicators Division. Accra Ghana. 2011. 
[7] Ghana Statistical Service. 2010 Population and Housing Census. Ghana Statistical Service National Data Archive. Accra Ghana. 2012.

[8] Glotfelty, D. E., and Schomburg, C. J. Volatilization of pesticide data reported in this paper, PELMO can be used for from soil. SSSA, Madison, WI. 1989. p. 181-206.

[9] IFAD. Annual Report. 2009. [Online] Available: http://www.ifad.org/pub/ar/2009/e/print.pdf [Accessed: 10 August 2014].

[10] Krishnapillai, S. and Thompson, H. Cross Section Translog Production and Elasticity of Substitution in U.S. Manufacturing Industry. International Journal of Energy Economics and Policy. 2012, Vol. 2, No. 2, p. 50-54. ISSN 2146-4553

[11] NEPAD School Feeding Programme. (2005b). NEPAD School Feeding Programme; Annual Operating Plan.

[12] Onumah, E. E. and De-Graft, A. H. A Stochastic Production Investigation of Fish Farms in Ghana. Agris on-line Papers in Economics and Informatics. 2011, Vol. III, No. 2. ISSN 1804-1930.

[13] Partnership for Child Development. Osun State Home Grown School Feeding and Health Programme. Case study. 2010. [Online] Available: hgsf-global.org/.../94-osun-state-hgsf-andhealth-programme-case-st... [Accessed: 9 March 2012].

[14] Stewart, J. Calculus. Early Transcendentals. Thomson Brooks/Cole, 6 ${ }^{\text {th }}$ Edition, 2008, p. 857 and 887. ISBN-10: 0495011665.

[15] Tomlinson, M. School feeding in east and southern Africa: Improving food sovereignty or photo opportunity? Equinet Discussion Paper Number 46. March 2007, Regional Network for Equity in Health in Southern Africa. South Africa. 207.

[16] Tshiunza, M., Lemchi, J. and Tenkouano, A. Determinants of Market Production of Cooking Banana in Nigeria. African Crop Science Journal. 2001, Vol. 9. No. 3, p. 537-547. ISSN 1021-9730.

[17] Tzouvelekas, E. Approximation Properties and Estimation of Translog Production Function with Panel Data. 2000. [Online] Available: http://ideas.repec.org/a/ags/jlaare/30959.html [Accessed: 19 Oct 2011].

[18] Wasim, M. A., Dwaipayan, S., Samsul, A., and Ashim, C. Degradation Dynamics Of A Di-Nitro Aniline Herbicide (Trifluralin) In/On Black Gram (Vigna Mungo) Under East-Indian Climatic Condition. Electronic Journal of Enviromental, Agricultural and Food Chemistry. 2009, Vol. 8, No. 11, p. 1172. ISSN 1579-4377

[19] World Bank (2011). World Bank Annual Report 2011. [Online] Available: http://web.worldbank. org/ [Accessed: 5 November 2013].

[20] World Food Programme (2007b). Home-Grown School Feeding A Framework To Link School Feeding with Local Agricultural Production 77. 